\title{
Characterization of Indonesian pigmented rice (Oryza sativa) based on morphology and Single Nucleotide Polymorphisms
}

\author{
NUR SITI KURNIASIH ${ }^{1}$, RATNA SUSANDARINI ${ }^{1}$, FEBRI ADI SUSANTO ${ }^{2}$, TRI RINI NURINGTYAS ${ }^{1,2}$, \\ GLYN JENKINS ${ }^{3}$, YEKTI ASIH PURWESTRI ${ }^{1,2, \varphi}$ \\ ${ }^{1}$ Departement of Tropical Biology, Faculty of Biology, Universitas Gadjah Mada. Jl. Teknika Selatan, Sekip Utara, Sleman 55281, Yogyakarta, \\ Indonesia. Tel./fax.: +62-274-580398, `email: yekti@ugm.ac.id \\ ${ }^{2}$ Research Center for Biotechnology, Universitas Gadjah Mada. Jl. Teknika Utara, Depok, Sleman 55281, Yogyakarta, Indonesia \\ ${ }^{3}$ Institute of Biological, Environmental and Rural Sciences, Aberystwyth University. Aberystwyth, United Kingdom
}

Manuscript received: 21 February 2018. Revision accepted: 29 March 2019.

\begin{abstract}
Kurniasih NS, Susandarini R, Susanto FA, Nuringtyas TR, Jenkins G, Purwestri YA. 2019. Characterization of Indonesian pigmented rice (Oryza sativa) based on morphology and Single Nucleotide Polymorphisms. Biodiversitas 20: 1208-1214. Indonesia has many cultivars of pigmented rice, but many variants have not been characterized using morphological characters and molecular markers. SNPs (Single Nucleotide polymorphisms) have been used in previous studies to identify the Indica and Japonica subspecies. Characterization of wheter a line belongs to the Indica or Japonica subspecies is useful information for rice breeders, especially to generate line exhibiting the strong hybrid vigor. Morphological characters are used to determine the relationship between cultivars using cluster analysis. The SNP markers were amplified by PCR, sequenced and compared with sequences in the GenBank. Based on morphological characters, ten cultivars divide into two clusters. SNPs distinguish Indica and Japonica subspecies, and show that Hitam Lampung, Aek Sibundong, Melik, Hitam Toraja, Merah Kalimantan, and Merah Sumbawa belong to the Indica subspecies while Cempo Ireng and Pare Eja belong to Japonica. Abang Segreng and Hitam Toraja could not be clearly assigned to either the Indica or Japonica subspecies.
\end{abstract}

Keywords: Morphological and molecular characterization, Oryza sativa, pigmented rice, SNP markers

\section{INTRODUCTION}

Rice (Oryza sativa L.) is the staple food for more than half the world's population (Thippeswamy et al. 2014). Based on the place of origin, rice is divided into 3 different subspecies or varietal groups, namely Sinica (Japonica), Javanica and Indica (Le heron et al. 2016). Based on the geographical distribution, plant and grain morphology, hybrid sterility and serological reaction, rice is divided into Indica and Japonica subspesies (Chang and Bardenas 1965). According to Thomson et al. (2007), 68\% of 330 rice accessions in Indonesia are Indica subspecies and 32\% are Japonica. The Indica subspecies has longer seeds, high stature, soft plant tissue, a large number of tillers, is fragile and has non-sticky textured seed, and it is responsive to temperature. The Japonica subspecies has rounded seeds, medium stature, small seedlings, and sticky textured seeds (Le heron et al. 2016; Tripathi et al. 2016).

Indonesia has many regions growing various pigmented rice landraces, each of which has a local name. Most of the rice cultivated by local communities is from local seeds that have not been characterized and certified. This is potentially confusing since one cultivar may have more than one name, and many local variants may actually be identical. In addition, the variation in phenotype of pigmented rice can cause problems in classification, especially with respect to distinguish both Indica and Japonica subspecies.
Characterization of pigmented rice can be performed using morphological characters as well as molecular markers which provide useful objective information for plant breeding efforts, especially for rice improvement (Supriyanti et al. 2015). Hybridization of Indica and Japonica subspecies will generate the strong hybrid vigor, which has increased rice yields such as increased biomass, size, and growth rate (Lu et al. 2009; Feng et al. 2015; Guo et al. 2016). According to Utami et al. (2009), the differences and similarities in morpho-physiological characters can be used for identification and are easier and cheaper than molecular markers (Sivarajan 1984). However, molecular markers can be used to characterize genotypes quickly and precisely.

SNPs (Single Nucleotide polymorphisms) are widely used as molecular markers and are based on the differences of one nucleotide [Singh et al. 2013; Vignal et al. 2002). SNPs were used to characterize many crops, such as cotton, rice, corn and tomato. Feltus et al. (2004) successfully identified 408,898 candidates of nucleotide polymorphism which can be used as SNPs markers to identify Indica and Japonica subspecies. Based on this research, 5 candidate SNPs are used to distinguish ten pigmented rice accessions into Indica and Japonica subspecies. This study is important and valuable for improvment and production of Indonesian pigmented rice. 


\section{MATERIALS AND METHODS}

\section{Materials}

Ten rice cultivars were obtained from local farms in Indonesia (Table 1). Nipponbare and Pokkali were obtained from Balai Benih Sukamandi, Bogor, Indonesia. Four replicate pots of each genotypes were grown in a green house from November 2017 until June 2018 under defined condition avoiding nutrient deficiency, pest and disease attack. Individuals of each genotype were planted in pots with four replications.

\section{Morphological characterization}

Thirty four morphological characters were observed and recorded from vegetative to reproductive growth stages based on Silitonga et al. (2003) and Biodiversity International (2007).

\section{Molecular characterization \\ DNA extraction}

DNA was extracted using the modification of Apitz et al. (2014). One hundred mg leaf tissue was extracted by grinding in $800 \mu \mathrm{l}$ of extraction buffer containing $2.42 \mathrm{~g}$ Tris- $\mathrm{HCl} \mathrm{pH} 8 ; 0.88 \mathrm{~g} \mathrm{NaCl} ; 5 \mathrm{ml}$ EDTA $0.5 \mathrm{M}$, and $10 \%$ SDS, followed by centrifugation at $13,000 \mathrm{rpm}$ at $4^{0} \mathrm{C}$ for 1 min. The DNA was precipitated by $700 \mu \mathrm{L}$ of isopropyl alcohol and was centrifuged for $15 \mathrm{~min}$ at 13,000 rpm and $4^{0} \mathrm{C}$. DNA was washed with $70 \%$ ethanol. DNA was dissolved in $50 \mu \mathrm{L} \mathrm{ddH_{2 }} \mathrm{O}$.

\section{DNA amplification}

Maxima Hot Start Green (Thermo Scientific, USA) was used to amplify DNA containing SNPs markers obtained from http: //www.plantgenome.uga.edu/snp. Primers used to amplify DNA containing Indica or Japonica SNPs were designed with Primary 3 software (Table 2). The DNA was sequenced using the BigDye ${ }^{\circledR}$ Terminator v3.1 cycle sequencing kit (Applied Biosystems, USA).

\section{Data analysis}

Morphological characters were analyzed using UPGMA cluster analysis to determine the similarity between cultivars, and principal component analysis to determine the significance of the characters in the grouping. Cluster analysis and principal component analysis were performed by the MVSP program (Kovach et al. 2007). Molecular characterization was performed by comparing the sequence of ten cultivars with the rice genome in GenBank.

\section{RESULTS AND DISCUSSION}

\section{Morphological characterization}

Pigmented rice consists of black, red, and purple variants. It has phenolic compounds, flavonoids, and anthocyanins (Goufo and Trindade 2014). Red and black rice were used in this study. Red rice consist of Aek Sibundong, Abang Segreng, Merah Kalimantan, Pare Eja and Merah Sumbawa. Black rice consist of Hitam Lampung, Melik, Cempo Ireng, Hitam Kalimantan, and Hitam Toraja. Ten cultivar show variation in morphological characters (Table 3; Figure 1). Planting period of ten cultivars varies between 110-215 days, the shortest is Abang Segreng and the longest is Hitam Kalimantan.

UPGMA (Unweighted Pair Group Method using Arithmetic average) cluster analysis was performed using Canberra distance. The cluster analysis of ten pigmented rice cultivars based on morphological character shows that the ten cultivars of rice can be divided into 2 different groups, A and B (Figure 2). The distinguishing characters are the awn, and extension from the lemmas of the rice florets (Figure 3). An awn is a fibrous bristle, formed as an extension of varying lengths from the the midrib (middle nerve) of the lemma. A group does not have an awn and B group has an awn can be short, medium and long.

Table 1. Ten rice cultivars and origin

\begin{tabular}{ll}
\hline Cultivars & Origin \\
\hline Red rice & \\
Abang Segreng & Gunung Kidul, Yogyakarta \\
Aek Sibundong & Balitbangtan \\
Merah Kalimantan & South Kalimantan \\
Merah Sumbawa & Sumbawa, West Nusa Tenggara \\
Pare Eja & Malino, South Sulawesi \\
Black rice & \\
Cempo Ireng & Gunung Kidul, Yogyakarta \\
Hitam Kalimantan & South Kalimantan \\
Hitam Lampung & South Lampung, Lampung \\
Hitam Toraja & Toraja, South Sulawesi \\
Melik & Bantul, Yogyakarta \\
\hline
\end{tabular}

Table 2. Primer used to amplify DNA containing the Indica-Japonica SNPs

\begin{tabular}{|c|c|c|c|c|c|c|}
\hline $\begin{array}{l}\text { Primer } \\
\text { code }\end{array}$ & Primer & Sequence & $\begin{array}{l}\text { PCR } \\
\text { product } \\
\text { (bp) }\end{array}$ & $\begin{array}{c}\text { Chromosome } \\
\text { number }\end{array}$ & $\begin{array}{c}\text { SNPs location } \\
\text { (base number in PCR } \\
\text { fragment/ rice genome) }\end{array}$ & $\begin{array}{l}\text { Annealing } \\
\quad\left({ }^{0} \mathrm{C}\right)\end{array}$ \\
\hline \multirow[t]{2}{*}{$\overline{\mathrm{A}}$} & Reverse & 5' GTTGGGTCAGGCGAGAAATC 3' & 160 & 12 & $76 / 2900$ & 54 \\
\hline & Forward & 5' TCACCAACAAGTACAAGCGC 3', & & & & \\
\hline \multirow[t]{2}{*}{ B } & Reverse & 5' ATGATGACAAGGGAGGTGACA 3' & 150 & 9 & $88 / 43,237,333$ & 54 \\
\hline & Forward & 5'TAACTTCAGGAGCCCTCTAACC 3' & & & & \\
\hline \multirow[t]{2}{*}{$\mathrm{C}$} & Reverse & 5'TTTTCTCCCAATCCGCTGCT 3' & 163 & 1 & $72 / 481,481$ & 54 \\
\hline & Forward & 5'ATTGGAGTCTTGCCGATGAG 3' & & & & \\
\hline \multirow[t]{2}{*}{$\mathrm{D}$} & Reverse & 5'TGCAGGAGTGACTTCAGGAA 3' & 162 & 8 & $52 / 72,058$ & 54 \\
\hline & Forward & 5' ATTGTGGTACTCGGCCTTGA 3' & & & & \\
\hline \multirow[t]{2}{*}{$\mathrm{E}$} & Reverse & 5'AAAGCTCCAGGGACCACATC 3' & 162 & 8 & $94 / 83,990$ & 54 \\
\hline & Forward & 5' GGCTGCTTGACACCCTTATG 3' & & & & \\
\hline
\end{tabular}



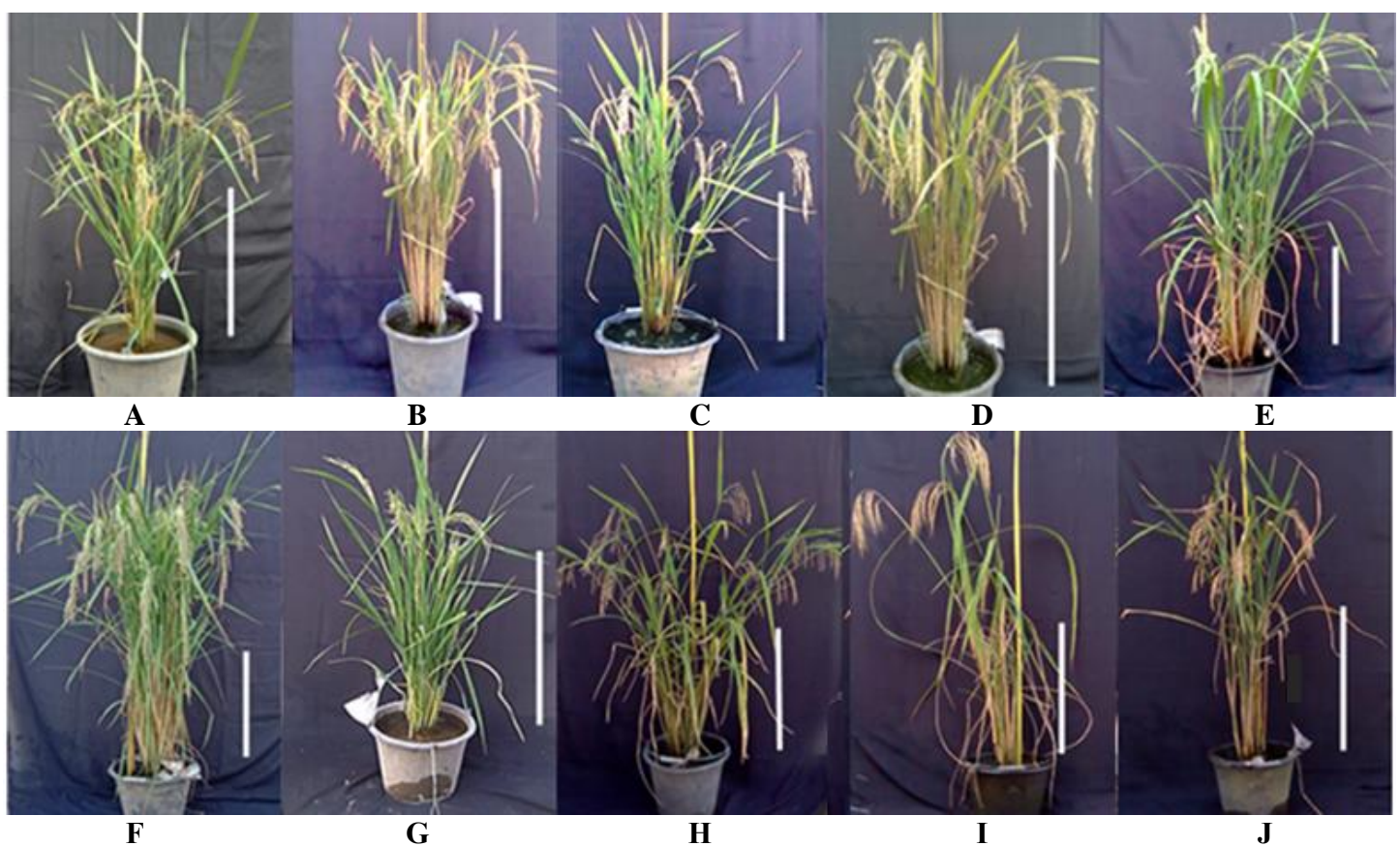

B

C

D

E
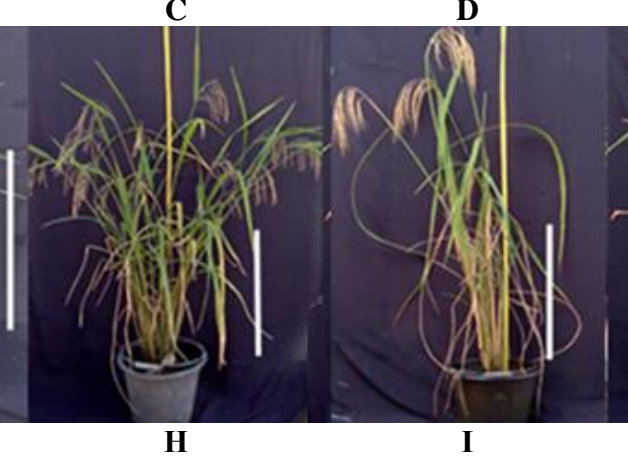

G

H

I

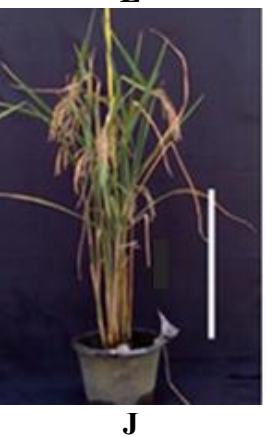

Figure 1. The cultivars of Indonesian pigmented rice used in this study. A. Hitam Lampung; B. Aek Sibundong; C. Abang Segreng; D. Melik; E. Cempo ireng; F. Hitam Kalimantan; G. Merah Kalimantan; H. Hitam Toraja; I. Pare eja; J. Merah Sumbawa. White bar = $50 \mathrm{~cm}$

Table 3. Variation in morphological characters

\begin{tabular}{|c|c|c|c|c|c|c|c|c|}
\hline Cultivars & $\begin{array}{l}\text { Planting } \\
\text { period } \\
\left(\text { dap* }^{*}\right)\end{array}$ & $\begin{array}{l}\text { Category of } \\
\text { awn length }\end{array}$ & $\begin{array}{c}\text { Anthocyanin } \\
\text { coloration of } \\
\text { leaf sheath }\end{array}$ & $\begin{array}{c}\text { Intensity of } \\
\text { green color } \\
\text { of } \\
\text { leaf blade }\end{array}$ & $\begin{array}{c}\text { Category of } \\
\text { diameter at } \\
\text { basal internode }\end{array}$ & $\begin{array}{l}\text { Apiculus } \\
\text { color }\end{array}$ & $\begin{array}{l}\text { Category of } \\
\text { Panicle } \\
\text { length }\end{array}$ & $\begin{array}{c}\text { Category of culm } \\
\text { length }\end{array}$ \\
\hline \multicolumn{9}{|l|}{ Red rice } \\
\hline Abang Segreng & 110 & Awnless & Medium & Dark & Thick & Purple & Short & Short \\
\hline Aek Sibundong & 114 & Intermediate & Absent & Light & Thin & White & Intermediate & Short \\
\hline Merah Kalimantan & 121 & Very short & Absent & Light & Thin & White & Intermediate & Very short-short \\
\hline Merah Sumbawa & 134 & Awnless & Absent & Light & Intermediate & White & Intermediate & Short \\
\hline Pare Eja & 127 & Very long & Absent & Light & Thick & White & Long & Very short-short \\
\hline \multicolumn{9}{|l|}{ Black rice } \\
\hline Cempo Ireng & 153 & Intermediate & Absent & Light & Thick & White & Long & Long \\
\hline Hitam Kalimantan & 215 & Very short & Absent & Light & Thin & White & Intermediate & Intermediate to long \\
\hline Hitam Lampung & 116 & Intermediate & Absent & Medium & Intermediate & White & Intermediate & Short \\
\hline Hitam Toraja & 128 & Awnless & Absent & Light & Intermediate & White & Intermediate & Short-intermediate \\
\hline Melik & 117 & Awnless & Absent & Medium & Intermediate & White & Intermediate & Very short-short \\
\hline Merah Sumbawa & 134 & Awnless & Absent & Light & Intermediate & White & Intermediate & Short \\
\hline
\end{tabular}

Note: dap*: day after planted; category of awn length: very short $(<5 \mathrm{~mm})$, intermediate $(\sim 15 \mathrm{~mm})$, and very long $(>40 \mathrm{~mm})$; category of diameter at basal internode: thin $(6-10 \mathrm{~mm})$, intermediate $(11-14 \mathrm{~mm})$ and thick $(15-18 \mathrm{~mm})$; category of panicle length: short $(\sim 15$ $\mathrm{cm})$, intermediate $(\sim 25 \mathrm{~cm})$, and long $(\sim 35 \mathrm{~cm})$; category of culm length: very short-short $(51-70 \mathrm{~cm})$, short $(71-90 \mathrm{~cm})$, shortintermediate $(91-105 \mathrm{~cm})$, intermediate-long $(121-140 \mathrm{~cm})$, and long $(141-155 \mathrm{~cm})$

The A group consists of Hitam Toraja, Merah Sumbawa, Melik and Abang Segreng. This group was further divided into 2 subgroups, A1 and A2 based on anthocyanin coloration of the leaf sheath, intensity of the green color of leaf blade, diameter at basal internode of the culm, apiculus color and panicle length. The A1 group contains Hitam Toraja, Merah Sumbawa and Melik which has a medium intensity of green color, intermediate basal internodes, white apiculus and intermediate panicle length. The A2 group contains Abang Segreng which had medium anthocyanin coloration in the leaf sheath, dark intensity of green colour, thick basal internode, purple apiculus, and short panicle length.

The B group was also divided into 2 subgroups, B1 and B2 based upon culm length. The B1 group consists of Hitam Kalimantan, Pare Eja and Cempo Ireng which have intermediate to long culm length $(135-146 \mathrm{~cm})$. The B2 group consists of Merah Kalimantan, Aek Sibundong and Hitam Lampung which have very short to short culm length $(60-85 \mathrm{~cm})$. 
Principal component analysis was performed to determine the dominant characters in characterization. From 34 morphological characters, 6 characters have eigenvalues $\geq 0.25$ (Table 4.) The morphological characters were anthocyanin coloration in the leaf sheath, flag leaf length, ligule color, apiculus color, lemma and palea color, and awn length. Leaf length, leaf width, ligule color, collar color, diameter at basal internode of culm panicle, and leaf sheath was significant characters in grouping (Shikari et al. 2009; Lestari et al. 2016).

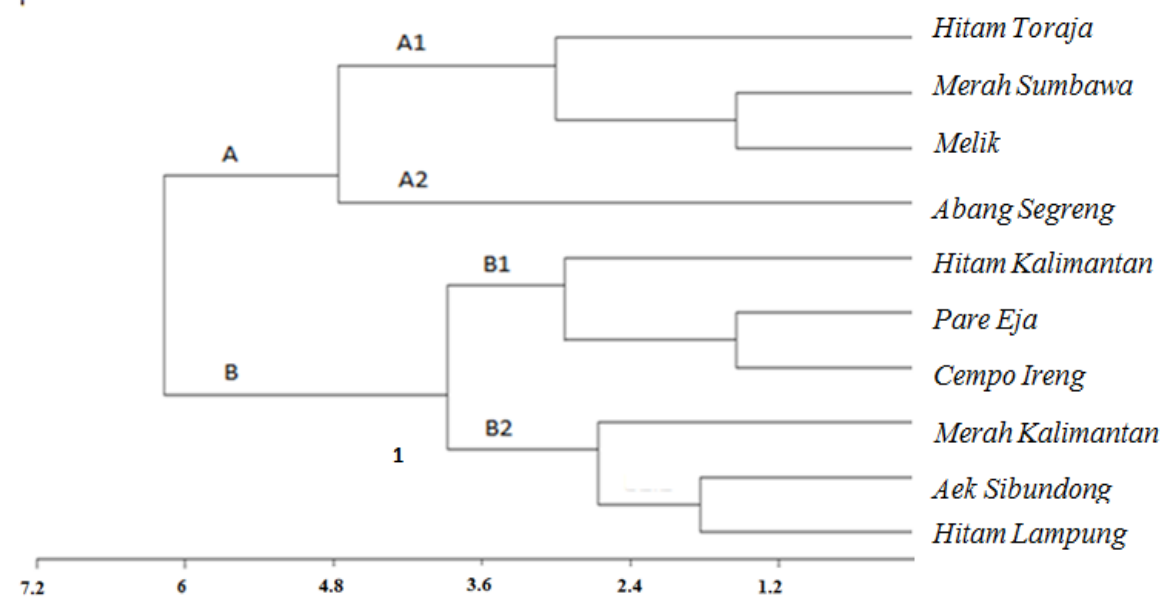

Figure 2. UPGMA dendrogram for morphological characters of 10 rice cultivars. The relationship was based on Canberra distance

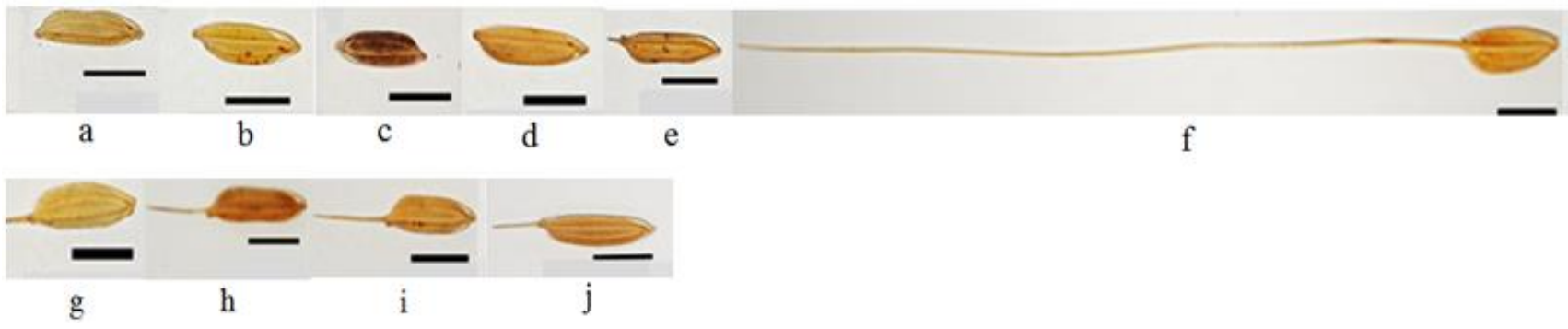

Figure 3. The seeds of ten cultivars of A group, i.e., A. Hitam Toraja; B. Merah Sumbawa; C. Melik, D. Abang Segreng; and B group, i.e., E. Hitam Kalimantan; F. Pare eja; G. Cempo ireng; H. Merah Kalimantan; I. Aek Sibundong; J. Hitam Lampung. Awn is indicated in cultivars E-J. Black bar $=5 \mathrm{~mm}$

Table 4. Eigenvalue of morphological characters in ten rice cultivars

\begin{tabular}{llllll}
\hline Morphological characters & Axis 1 & Axis 2 & Morphological characters & Axis 1 & Axis 2 \\
\hline Anthocyanin coloration of coleoptile & 0.000 & 0.000 & Culm habit & 0.140 & 0.112 \\
Seedling height & 0.174 & 0.037 & Culm length & 0.195 & -0.094 \\
Basal leaf sheath coloration & 0.097 & 0.169 & Culm number & 0.248 & 0.009 \\
Anthocyanin coloration in leaf sheath & 0.030 & $\mathbf{0 . 3 9 1}$ & Diameter at basal internode & 0.223 & 0.057 \\
Intensity of green color: leaf blade & 0.196 & 0.166 & Stigma color & 0.102 & 0.248 \\
Leaf blade attitude & 0.102 & -0.046 & Lemma and palea color & $\mathbf{0 . 2 7 9}$ & 0.069 \\
Leaf blade pubescence & 0.157 & 0.063 & Apiculus color & 0.106 & $\mathbf{0 . 3 1 6}$ \\
Auricle color & 0.129 & 0.034 & Panicle length & 0.229 & -0.099 \\
Ligule length & 0.240 & 0.000 & Awn color & 0.058 & -0.135 \\
Ligule character & 0.055 & 0.085 & Awn length & 0.118 & $\mathbf{- 0 . 5 6 3}$ \\
Ligule Shape & 0.202 & -0.068 & Panicle number per plant & 0.187 & 0.003 \\
Ligule color & 0.109 & $\mathbf{0 . 2 5 5}$ & Attitude of panicle & 0.107 & -0.080 \\
Leaf blade length & 0.237 & -0.009 & Secondary branching of panicle & 0.139 & 0.022 \\
Leaf Blade width & 0.230 & 0.013 & Panicle exsertion & 0.247 & 0.003 \\
Flag leaf length & 0.179 & $\mathbf{- 0 . 3 1 4}$ & Awn color (harvest) & 0.063 & -0.237 \\
Flag leaf width & 0.206 & -0.070 & Lemma and palea color (harvest) & 0.169 & 0.030 \\
Flag leaf attitude & 0.121 & -0.038 & Seed color & 0.245 & 0.000 \\
\hline
\end{tabular}




\section{Characterization of pigmented rice using SNPs}

Morphological characters such as seed shape, apiculus, awn length, leaf colour or biochemical assay can be used to characterize Indica and Japonica subspecies (Kovach et al. 2007; Du et al. 2011). However, morphological characters are variable under different environmental conditions. Molecular markers are more stable than morphological characters. SNPs are the predominant polymorphisms in the genome (McNally et al 2009). SNPs as molecular markers were used to identify many crops, such as cotton, rice, corn and tomato (Byers et al. 2012; Chen et al. 2016; Huq et al. 2016).

To assay the effectiveness of the SNPs markers, 5 candidate SNPs were used to distinguish Pokkali and Nipponbare. Nipponbare was assigned to the Japonica group (Matsumoto et al. 2016; Ahn et al. 2016; Huang et al. 2002) and Pokkali was assigned to the Indica group (Lee 2010). B and C primers can be used to amplify DNA containing these SNPs and to distinguish Indica and Japonica subspecies (Figure 4).

As can be seen in figure 5, PCR fragments from primers $\mathrm{B}$ and $\mathrm{C}$ show that the Hitam Lampung, Aek Sibundong, Melik, Hitam Kalimantan, Merah Kalimantan, and Merah Sumbawa had the same SNPs as Pokkali (Indica subspecies). Cempo Ireng and Pare Eja had the same SNPs as Nipponbare (Japonica subspecies). Hitam Toraja and Abang Segreng share SNPs with Pokkali and Nipponbare. This indicates that the B and C SNP markers did not clearly distinguish between Hitam Toraja and Abang Segreng. Therefore, more SNPs markers are needed to anticipate possible gene recombination.

\section{Comparison of morphological and molecular characterization}

Cluster analysis is widely used in plant systematics. The grouping of accessions in this analysis is based on similarities and differences between characteristics (Henderson 2006). Based on morphological and molecular characterization, the color of seed does not determine the groupping of rice. Based on morphological characters, ten cultivars are divided into 2 groups, A and B group. However, based on molecular characterization, ten cultivars are divided into 3 groups, Indica, Japonica and
Indica-Japonica (Table 5.). Indica-Japonica subspecies has same nucleotide as Indica and Japonica. Interestingly, morphological analysis show that Pare Eja and Cempo Ireng are included in the Japonica subspecies. The dendogram of the clustering analysis showed that both cultivars are included into the same group (A group) and have a close phylogenetic relationship.

The results of the molecular analysis indicate that Hitam Toraja and Abang Segreng are included in Indica and Japonica subspecies respectively. The dendogram of the clustering analysis of morphological data showed that both cultivars are included in group B. Molecular analysis indicated that Merah Sumbawa, Melik, Hitam Kalimantan, Merah Kalimantan, Aek Sibundong and Hitam Lampung are included in the Indica subspecies. In contrast, the dendogram of the clustering analysis shows that Merah Sumbawa and Melik fall into different groups than the others, indicating that morphological grouping patterns are not always consistent with molecular grouping.

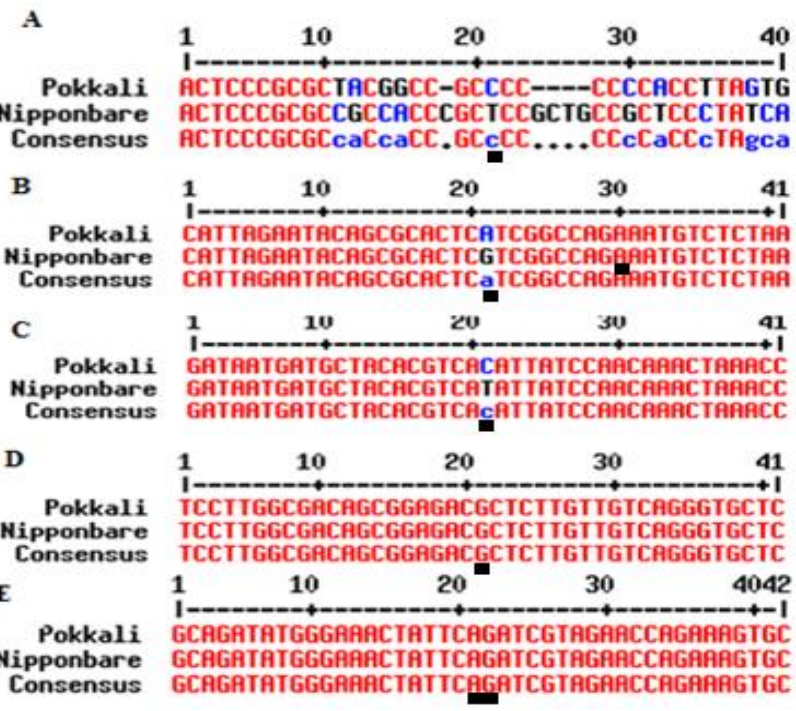

Figure 4. Alignment of Nipponbare and Pokkali sequences using $\mathrm{A}, \mathrm{B}, \mathrm{C}, \mathrm{D}$, and $\mathrm{E}$ primers. Black squares indicate the location of SNPs

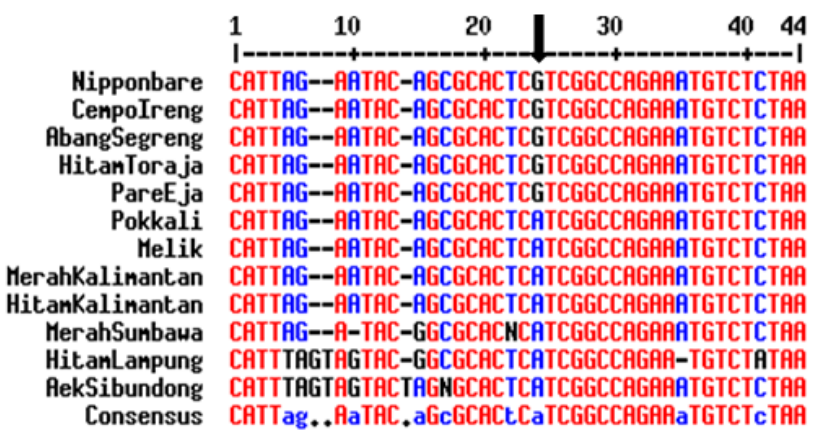

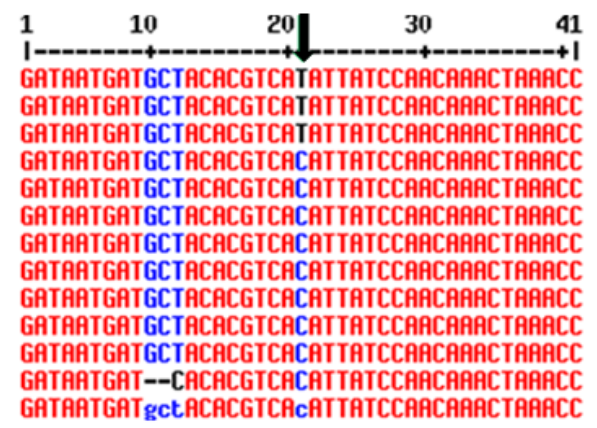

Figure 5. Alignment result of ten cultivars using (1) B and (2) C primers. The black arrows show the location of SNPs 
Table 5. Result of morphological and molecular characterization of ten cultivars

\begin{tabular}{llll}
\hline Morphological characterization & & Molecular characterization & \\
\hline Cultivars & Group & Cultivars & Subspecies \\
\hline Red rice & & Red rice & Indica-Japonica \\
Abang Segreng & A & Abang Segreng & Indica \\
Merah Kalimantan & B & Aer Sibundong & Indica \\
Aek Sibundong & B & Merah Sumbawa & Indica \\
Merah Sumbawa & A & Pare Eja & Japonica \\
Pare Eja & B & Black rice & Japonica \\
Black rice & & Cempo Ireng & Indica \\
Cempo Ireng & B & Hitam Kalimantan & Indica \\
Hitam Kalimantan & B & Hitam Lampung & Indica-Japonica \\
Hitam Lampung & B & Hitam Toraja & Indica \\
Hitam Toraja & A & Melik & \\
Melik & A & & \\
\hline
\end{tabular}

In order to classify various Indonesian rice variants and to eliminate collection duplication, we have started out with five primer pairs to investigate differences between 10 local cultivars. Three of these pairs (A, D and E) were not informative. We suggest using primer pairs $\mathrm{B}$ and $\mathrm{C}$ as basic tools to set up a comprehensive catalogue of local rice variants in Indonesia. This primer tool-box has to be extended in the future to generate comparable data and to augment the management of pigmented rice germplasm.

\section{ACKNOWLEDGEMENTS}

This research was partially funded by PUPT (Penelitian Unggulan Perguruan Tinggi) Competitive Research Grant 2016, The Indonesian Ministry of Research, Technology, and Higher Education to YAP contract number 863/UN1P.III/LT/DIT-LIT/2016 and Program Penguatan Kelembagaan Pusat Studi Menuju Keunggulan Akademik Universitas Gadjah Mada 2018 contract number 4104/UNI/DITLIT/DIT-LIT/LT/2018. Glyn Jenkins was supported by World Class Professor Program (WCP) contract number 168.A10/D2/KP/2017. We thank pigmented rice research group members at Research Center for Biotechnology, Gadjah Mada University (UGM), Yogyakarta and Faculty of Biology, UGM, Yogyakarta for all supports and the discussions to improve this manuscript.

\section{REFERENCES}

Ahn JC, Kim D-W, You YN, Seok MS, Park JM, Hwang H, Kim B-G, Luan S, Park H-S, Cho HS. 2010. Classification of rice (Oryza sativa L. Japonica Nipponbare) immunophilins (fkbps, cyps) and expression patterns under water stress. BMC Plant Biol 10: 253. DOI: 10.1186/1471-2229-10-253.

Apitz J, Schmied J, Lehmann M, Hedtke B, Grimm B. 2014. GluTR2 complements a hema1 mutant lacking glutamyl-trna reductase 1, but is Differently Regulated at the Post-Translational Level. Plant Cell Physiol 55: 645-657.

Bioversity International. 2007. Descriptors for Wild and Cultivated Rice (Oryza spp.). Biodiversity International, Rome.
Byers RL, Harker DB, Yourstone SM, Maughan PJ, Udall JA. 2012. Development and mapping of SNP assays in allotetraploid cotton. Theor Appl Genet 124: 1201-1214.

Chang TT and Bardenas EA. 1965. The Morphology and Varietal Characteristics of the Rice Plant. The International Rice Research Institute, Manila.

Chen Q, Mao X, Zhang Z, Zhu R, Yin Z, Yu H, Jia H, Jiang S, Ni Z, Jiang H, Han X, Liu C, Qi Z. 2016. SNP-SNP interaction analysis on soybean oil content under multi-environments. PLoS One 11 (9): e0163692. DOI: 10.1371/journal.pone.0163692

Du H, Ouyang Y, Zhang C, Zhang Q. 2011. Complex evolution of s5, a major reproductive barrier regulator, in the cultivated rice Oryza sativa and its wild relatives. New Phytol 191: 275-287.

Feltus FA, Wan J, Schulze SR, Estill JC, Jiang N, Paterson AH. 2004. An SNP resource for rice genetics and breeding. Genome Res 14: 18121819 .

Feng S, Chen X, Wu S, Chen X. 2015. Recent advances in understand plant heterosis. Agric Sci 6: 1033-1038.

Goufo P, Trindade H. 2014. Rice antioxidants: phenolic acids, flavonoids, anthocyanins, proanthocyanidins, tocopherols, tocotrienols, $\gamma$ oryzanol, and phytic acid. Food Sci Netr 2: 75-104.

Guo J, Xu X, Li W, Zhu W, Zhu H, Liu Z, Luan X, Dai Z, Liu G, Zhang Z, Zeng R, Tang G, Fu X, Wang S, Zhang G. 2016. Overcoming inter-subspecific hybrid sterility in rice by developing indicacompatible japonica lines. Sci Rep 6: 26878-26886.

Henderson A. 2006. Traditional morphometrics in plant systematic and its role in palm systematic. Bot. J.Linn. Soc 151: 103-111.

Huang TJ, Kirk B, Favis R, Soussi T, Paty P. 2002. An endonuclease/ligase-based mutation scanning method especially suited for analysis of neoplastic tissue. Oncogene 21: 1909-1921.

Huq MdA, Akter S. Nou IS, Kim HT, Jung YJ, Kang KK. 2016. Identification of functional SNPs in genes and their effects on plant phenotypes. J Pant Biotechnol 43: 1-11. DOI: 10.5010/JPB.2016.43.1.1.

Kovach MJ, Sweeney MT, McCouch SR. 2007. New insights into the history of rice domestication. Trends Genet 23: 578-587.

Le Heron R, Campbell H, Lewis N, Carolan M. 2016. Biological Economies: Experimentation and the Politics of Agri-food Frontiers. Routledge, London.

Lee K-S, Choi W-Y, Ko J-C, Kim T-S, Gregorio GB. 2003. Salinity tolerance of japonica and indica rice (Oryza sativa L.) at the seedling stage. Planta 216: 1043-1046.

Lestari P, Utami DW, Rosdianti I, Sabran M. 2016. Morphological variability of Indonesian rice germplasm and the associated SNP markers. Emirates J Food Agric 28: 660-670.

Lu B-R, Cai X, Jin X. 2009. Efficient indica and japonica rice identification based on the InDel molecular method: Its implication in rice breeding and evolutionary research. Nat Sci 19: 1241-1252.

Matsumoto T, Wu J, Itoh T, Numa H, Antonio B, Sasaki T. 2016. The nipponbare genome and the next generation of rice genomics research in Japan. Rice 9: 1-11.

McNally KL, Childs KL, Bohnert R, Davidson RM, Zhao K, Ulat VJ, Zellerc G, Clark RM, Hoen DR, Bureau TE, Stokowski R, Ballinger 
DG, Frazerh KA, Cox DR, Padhukasahasram, Bustamante CD, Weigel D, Mackill DJ, Bruskiewich RM, Ratsch G, Buell R, Leung H, Leach JE. 2009. Genomewide snp variation reveals relationships. Proc Nat Acad Sci USA 106 : 12273-12278.

Shikari AB, Parray GA, Rather AG, Sheikh FA. 2009. Principal component analysis for evaluation of rice (Oryza sativa L.) germplasm. J. Rice Res 2: 16-22.

Silitonga TS, Somantri IH, Daradjat AA, Kurniawan H. 2003. Panduan Sistem Karakterisasi dan Evaluasi Tanaman Padi. Departemen Pertanian Badan Penelitian dan pengembangan Pertanian Komisi Nasional Plasma Nutfah, Bogor. [Indonesian]

Singh N, Choudhury DR, Singh AK, Kumar S, Srinivasan K, Tyagi RK, Singh NK, Singh R. 2013. Comparison of SSR and SNP marker in estimation of genetic diversity and population structure of indian rice $\begin{array}{llllll}\text { varieties. PLoS One } 8 \text { (12): e84136. DOI: } & \end{array}$ 10.1371/journal.pone.0084136.

Sivarajan VV. 1984. Introduction to the Principles of Plant Taxonomy. Cambridge University Press, Cambridge.
Supriyanti A, Supriyanta, Kristamtini. 2015. Karakterisasi dua puluh padi (Oryza sativa L) lokal di Daerah Istimewa Yogyakarta. Vegetalika 4: 29-41. [Indonesian]

Thippeswamy S, Chandramohan Y, Madhavilatha B, Pravilika K, Samreen Z, Bhoomeshwar K, Vinod G., Kalpana E. 2014. Identification of rice (Oryza sativa L.) varieties for prevention of type ii diabetes. Intl J Curr Res 6: 9123-9128.

Thomson M, Chin JH. 2014. Application of indica-japonica single nucleotide polymorphism markers for diversity analysis of Oryza AA genome species. Genet Res Characterization Utilization 12: 36-40.

Tripathi KK, Warrier R, Govila OP, Ahuja V. 2011. Biology of Oryza sativa L. (Rice). Department of Biotechnology, Government of India and Ministry of Environment \& Forests Government of India, New Delhi.

Utami DW, kristamtini dan Prajitno. 2009. Karakterisasi plasma nutfah padi beras merah lokal Yogyakarta berdasarkan karakter morfoagronomi dan marka ssrs. Zuriat 20: 10-18. [Indonesian]

Vignal A, Millan D, SanCristobal M, Eggen A. 2002. A review on SNP and other types of molecular markers and their use in animal genetics. Genet Sel Evol 34: 275-305. 